\title{
Optimal Control of a Mathematical Model of Smoking with Temporary Quitters and Permanent Quitters
}

\author{
Kontrol Optimal Model Matematika Merokok dengan Perokok \\ Berhenti Sementara dan Perokok Berhenti Permanen
}

\author{
Andi Utari Samsir ${ }^{1^{*}}$, Syamsuddin Toaha $^{2^{*}}$, Kasbawati $^{3^{*}}$
}

\begin{abstract}
This article discusses the optimal control of a mathematical model on smoking. This model consists of six population classes, namely potential to become smoker (P), snuffing class $(\mathrm{S})$, irregular smokers $(X)$, regular smokers $(Y)$, temporary quitters $\left(Q_{t}\right)$, and permanent quitters $\left(Q_{p}\right)$. The completion of this research uses the Pontryagin minimum principle and numerically using the forward-backward Sweep method. Numerical simulations of the optimal problem show that with the implementation of education campaigns and anti-nicotine medicine, the smokers can be decreased more quickly and the smoking population who quit permanently can be increased. The implementation of both through large amounts needs to be done from the beginning. The use of control in the form of education campaigns is of great value until the end of the research period means that it needs to be done continuously to reduce the number of smokers in the population.
\end{abstract}

Keywords: Mathematical Model on Smoking, Pontryagin Minimum Principle, ForwardBackward Sweep Method, Optimal Control.

\begin{abstract}
Abstrak
Artikel ini membahas tentang kontrol optimal model matematika merokok. Model ini terdiri dari enam kelas populasi, yaitu berpotensi sebagai perokok atau Potential Smokers (P), Snuffing Class $(S)$, perokok tidak aktif atau Irregular Smokers $(X)$, perokok aktif atau Regular Smokers $(Y)$, perokok yang berhenti sementara atau Temporary Quitters $\left(Q_{t}\right)$, dan perokok yang berhenti permanen atau Permanent Quitters $\left(Q_{p}\right)$. Sistem diselesaikan dengan menggunakan prinsip minimum Pontryagin dan secara numerik diselesaikan dengan metode forward-backward Sweep. Simulasi numerik dari masalah optimal menunjukkan bahwa dengan adanya penerapan kampanye edukasi dan pemberian obat anti nikotin maka perilaku merokok lebih cepat berkurang dan populasi perokok yang berhenti permanen akan meningkat. Penerapan kedua kontrol tersebut dalam jumlah besar perlu dilakukan sejak awal. Penggunaan kontrol berupa kampanye edukasi bernilai besar hingga akhir tahun pengamatan artinya untuk menekan jumlah populasi perokok secara maksimal, kampanye edukasi harus dilakukan secara terus menerus.
\end{abstract}

Kata Kunci: Model Matematika Merokok, Prinsip Minimum Pontryagin, Metode Forward-Backward Sweep, Kontrol Optimal.

*Program Studi Magister Matematika FMIPA-UNHAS

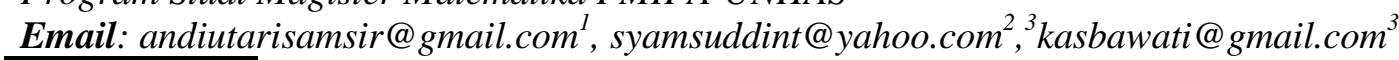

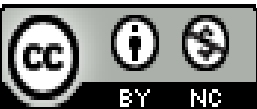

This work is licensed under a Creative Commons Attribution-NonCommercial 4.0 International License 


\section{Jumal Matematika, Statistika \& Komputasi Andi Utari Samsir, Syamsuddin Toaha, Kasbawati}

\section{Pendahuluan}

Dinamika perubahan populasi merupakan salah satu kajian dalam pemodelan matematika yang mencoba mendeskripsikan fenomena dari sudut pandang matematika [6]. Model matematika memberikan kemudahan dalam menyelesaikan masalah dalam kehidupan nyata [1]. Model ini digunakan untuk menjelaskan karakteristik fenomena yang dimodelkannya secara kualitatif atau kuantitatif, yang dibuat dengan melibatkan asumsi - asumsi yang didasarkan atas eksperimen atau observasi terhadap fenomena sebenarnya [7]. Salah satu fenomena yang dapat dimodelkan secara matematika adalah perilaku merokok.

Terdapat berbagai bahaya yang ditimbulkan oleh rokok, tidak hanya bagi perokok itu sendiri melainkan bahaya bagi orang lain disekitarnya [16]. Merokok merupakan bentuk utama penggunaan tembakau. Tembakau menjadi penyebab tunggal kematian utama yang dapat dicegah. Berdasarkan laporan World Health Organization (WHO) per Desember 2019, lebih dari 8 juta orang meninggal setiap tahunnya karena penggunaan tembakau. Lebih dari 7 juta kematian tersebut berasal dari penggunaan tembakau secara langsung sementara sekitar 1,2 juta disebabkan oleh aktivitas penggunaan tembakau [20].

Indonesia merupakan produsen rokok terbesar di dunia setelah China dan menjadi negara pertama dengan produksi rokok tertinggi di ASEAN. Berdasarkan data Riset Kesehatan Dasar tahun 2018, prevalensi perokok usia di atas 15 tahun mencapai 33,8 persen dan pada remaja usia 10-18 tahun mengalami peningkatan dari tahun 2013 sebesar 7,2 persen menjadi 9,1 persen di tahun 2018. Prevalensi perokok laki-laki usia di atas 15 tahun masih berada pada angka yang tinggi yaitu 62,9 persen dan menjadi prevalensi perokok laki-laki tertinggi di dunia [11].

Model matematika merokok pertama kali diperkenalkan oleh Garsow, dkk pada tahun 1997 [9]. Pada model tersebut, populasi terbagi menjadi tiga kelas yaitu potential smokers atau orang yang tidak merokok namun memiliki potensi untuk menjadi perokok dimasa depan, kemudian kelas perokok dan kelas orang yang berhenti merokok. Model tersebut kemudian dikembangkan oleh Sharomi \& Gumel pada tahun 2008 dengan membagi kelas perokok menjadi dua yaitu mild smokers dan chain smokers [17]. Zaman menganalisis model berhenti merokok Garsow dengan mempertimbangkan kelas occasional smokers dan menyajikan perilaku kualitatif pada model [21]. Zeb, dkk pada tahun 2013 menyajikan model berhenti merokok yang baru berdasarkan model Zaman dimana interaksi antara potential smokers dan occasional smokers adalah akar kuadrat [23] kemudian Din dan rekan-rekannya pada tahun 2016 memodifikasi model Zeb dengan menambahkan kompartemen perokok yang menderita penyakit [8]. Guerrero menggunakan model matematika untuk menggambarkan karakteristik kebiasaan merokok di Spanyol pada tahun 2011 [10]. Pada tahun 2013, Alkhudari,dkk mengadopsi dan mengembangkan penelitian Sharomi dan Gumel dengan mempertimbangkan efek teman sebaya pada perokok berhenti sementara [2], kemudian pada penelitian selanjutnya berdasarkan model yang telah diperoleh, mereka mengkaji mengenai pengaruh occasional smokers terhadap potential smoker [3] dan pada tahun 2015 mengkaji mengenai pengaruh heavy smokers terhadap potential smokers [4]. Matintu mengembangkan model baru berdasarkan ide yang diberikan oleh ketiga penelitian Alkhudhari dan rekannya [2,3,4] dengan mempertimbangkan efek dari heavy smokers dan occasional smokers terhadap potential smokers dan efek dari heavy smokers terhadap perokok berhenti sementara [13]. Pang,dkk pada tahun 2015 mempertimbangkan penyediaan tempat khusus merokok dan peningkatan harga rokok dalam mengendalikan perokok di China [14].

Dalam mengurangi perilaku merokok, beberapa peneliti menerapkan kontrol optimal $[5,15$, 18, 19, 22]. Pada tahun 2019, Pang, dkk [15] mengkaji mengenai pengendalian optimal dalam mengontrol penggunaan tembakau. Dalam penelitian tersebut dideskripsikan model kontrol dengan teori kontrol optimal untuk mengurangi jumlah perokok dengan menerapkan dua macam strategi yaitu media dan pengobatan berhenti merokok. Populasi perokok dibagi dalam enam kompartemen yaitu perokok potensial, perokok tidak aktif, perokok aktif, perokok yang berhenti sementara, perokok yang berhenti secara permanen, dan pasien karena merokok. 


\section{Jumal Matematika, Statistika \& Komputasi Andi Utari Samsir, Syamsuddin Toaha, Kasbawati}

Selanjutnya, penelitian yang ditulis oleh Alzahrani dan Zeb [5] menjelaskan mengenai strategi pencegahan pada model dinamik perilaku merokok dan analisis kontrol optimalnya. Pada analisis kontrol optimalnya diberikan dua strategi yaitu kampanye edukasi dan obat anti nikotin. Penelitian tersebut membagi populasi dalam lima kompartemen yaitu populasi rentan merokok, kelas menghirup tembakau atau snuffing class, perokok tidak aktif, perokok aktif, dan populasi berhenti merokok.

Dalam penelitian ini, model yang dikaji oleh Alzahrani dan Zeb [5] dikembangkan dengan membagi kompartemen berhenti merokok menjadi dua kompartemen yaitu perokok yang berhenti sementara dan perokok yang berhenti secara permanen seperti yang dimuat pada penelitian Pang, dkk [15] dengan tetap memperhatikan kompartemen berhenti merokok pada penelitian Alzahrani dan Zeb [5]. Pada penelitian ini pula diberikan dua macam strategi dalam mengendalikan konsumsi rokok yaitu kampanye edukasi dan obat anti nikotin.

\section{Model Matematika Perilaku Merokok}

Model dalam penelitian ini merupakan pengembangan model perilaku merokok menurut Alzahrani dan Zeb [5] dengan mengadopsi model Pang, dkk [15]. Hasil pengembangan model yang diperoleh adalah enam kompartemen, yaitu potential smokers $(P)$, snuffing class $(S)$, irregular smokers $(X)$, regular smokers $(Y)$, temporary quiters $\left(Q_{t}\right)$, permanent quitters $\left(Q_{p}\right)$. Pengembangan model dilakukan dengan membagi kelas quit smokers menjadi temporary quitters $\left(Q_{t}\right)$ dan permanent quitters $\left(Q_{p}\right)$ dan menambahkan beberapa faktor dalam upaya menekan perilaku merokok.

Adapun asumsi yang dibentuk sebagai berikut:

1. Setiap individu yang lahir dan migrasi diasumsikan bukan perokok dan rentan terhadap perilaku merokok masuk ke dalam kompartemen potential smokers $(P)$ dengan laju masukan sebesar $\Lambda$ individu per satuan waktu.

2. Kompartemen snuffing class $(S)$ merupakan individu yang merokok dengan menggunakan tembakau bubuk yang ditempatkan di dekat hidung dan dihirup secara langsung.

3. Snuff bersifat adiktif atau menimbulkan kecanduan karena adanya pengaruh nikotin. Hal ini membuat penggunanya sulit lepas dan akan memberikan pengaruh terhadap potential smokers $(P)$ untuk mencoba dan menjadi pengguna snuff.

4. Laju interaksi antara populasi rentan potential smokers (P) dengan snuffing class (S) adalah sebesar $\beta_{1}$ per satuan waktu.

5. Diasumsikan setiap populasi berkurang karena kematian alami dengan laju keluaran sebesar $\mu$ per satuan waktu.

6. Interaksi antara populasi pada snuffing class $(S)$ dan irregular smokers $(X)$ dengan laju sebesar $\beta_{2}$ individu per satuan waktu.

7. Diasumsikan bahwa populasi pada snuffing class $(S)$ berkurang karena penggunaan tembakau dengan laju sebesar $\rho$.

8. Populasi pada irregular smokers $(X)$ berkurang karena adanya individu yang menjadi regular smokers $(Y)$ dengan laju sebesar $\omega$ dan karena adanya kematian oleh penyakit yang disebabkan karena penggunaan tembakau dengan laju sebesar $\eta$.

9. Diasumsikan bahwa individu yang berhenti merokok secara sementara dapat kembali kambuh atau memiliki keinginan untuk kembali merokok dengan laju sebesar $\alpha$ per satuan waktu.

10. Populasi perokok berkurang ketika perokok berhenti untuk merokok dengan laju sebesar $\gamma$ per satuan waktu.

11. Perokok dengan proporsi $\delta$ adalah perokok yang berhenti secara sementara sedangkan perokok dengan proporsi $(1-\delta)$ adalah perokok yang berhenti secara permanen.

12. Diasumsikan bahwa perokok yang berhenti untuk sementara hanya dapat kembali menjadi regular smokers. 


\section{Jumal Matematika, Statistika \& Komputasi \\ Andi Utari Samsir, Syamsuddin Toaha, Kasbawati}

13. Populasi dalam snuffing class $(S)$ akan menjadi perokok hanya jika berinteraksi dengan perokok tidak aktif atau irregular smokers $(X)$.

14. Diasumsikan bahwa individu yang telah berhenti merokok tidak dapat dimasukkan lagi ke dalam kelas potential smokers $(P)$ karena dianggap bahwa kebiasaan merokok tersebut dapat kambuh kembali.

15. Diasumsikan bahwa proporsi dari kampanye edukasi $u_{1}(t)$ yang diberikan dapat mengurangi perilaku merokok.

16. Penambahan kontrol lain yaitu berupa obat anti nikotin $u_{2}(t)$ bertujuan untuk membuat individu dapat berhenti merokok.

Diagram kompartemen dari model berdasarkan asumsi-asumsi di atas ditunjukkan pada Gambar 2.1

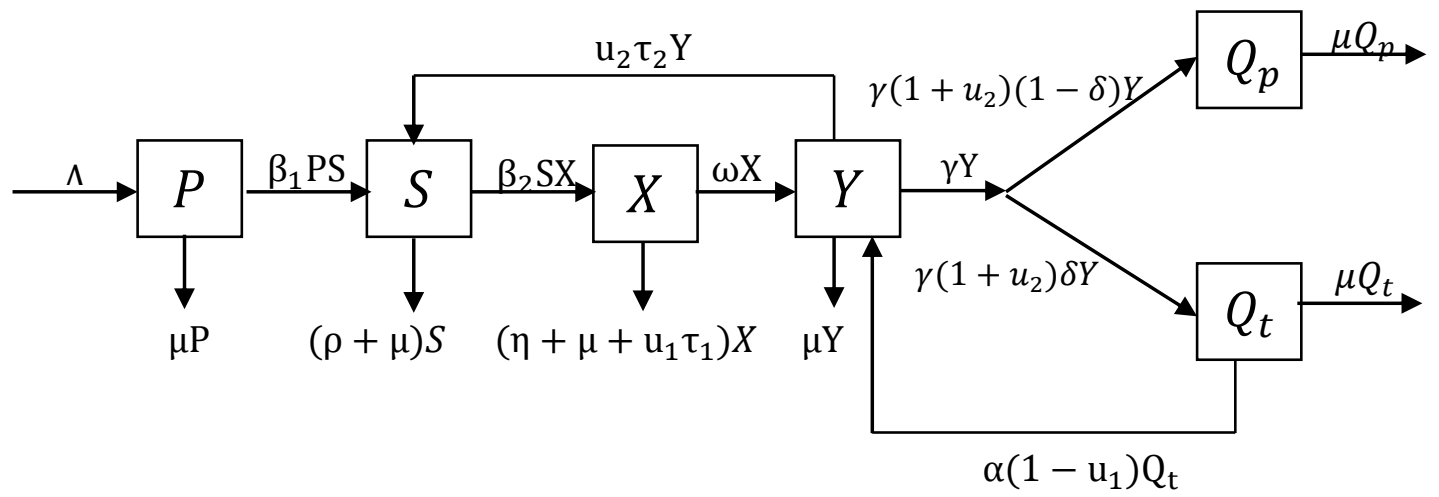

Gambar 2.1 Diagram Kompartemen Model Matematika Perilaku Merokok

Dari diagram kompartemen tersebut, diperoleh sistem persamaan differensial berikut:

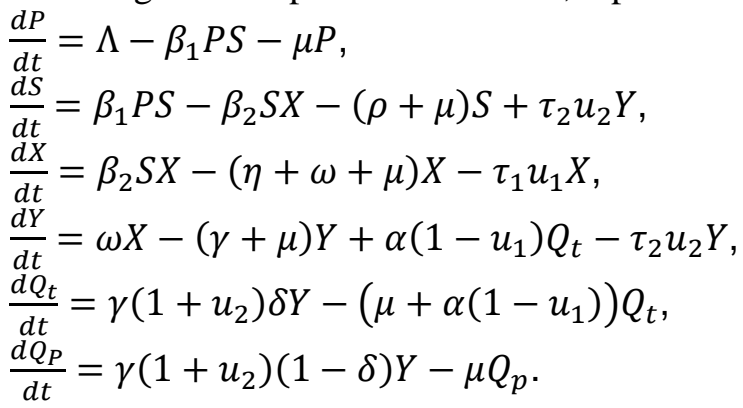

Diasumsikan bahwa kondisi awal memenuhi :

$$
P(0)>0, S(0) \geq 0, X(0) \geq 0, Y(0) \geq 0, Q_{t}(0) \geq 0, Q_{p}(0) \geq 0 .
$$

Keterangan variabel dan parameter yang digunakan dijelaskan pada Tabel 2.1

Tabel 2.1 Deskripsi Parameter dan Variabel Model

\begin{tabular}{clll}
\hline Simbol & \multicolumn{1}{c}{ Keterangan } & Satuan \\
\hline$P(t)$ & $\begin{array}{l}\text { Populasi yang berpotensi menjadi perokok } \\
\text { (potential smokers) pada waktu } t\end{array}$ & Orang \\
\hline$S(t)$ & $\begin{array}{l}\text { Populasi yang berada pada snuffing class pada } \\
\text { waktu } t\end{array}$ & Orang \\
\hline$X(t)$ & $\begin{array}{l}\text { Populasi yang tidak sering merokok (irregular } \\
\text { smokers) pada waktu } t\end{array}$ & Orang \\
\hline$Y(t)$ & $\begin{array}{l}\text { Populasi yang sering merokok (regular smokers) } \\
\text { pada waktu } t\end{array}$ & Orang \\
\hline$Q_{t}(t)$ & Populasi perokok yang berhenti sementara & Orang \\
\hline
\end{tabular}


Jumal Matematika, Statistika \& Komputasi Andi Utari Samsir, Syamsuddin Toaha, Kasbawati

\begin{tabular}{|c|c|c|}
\hline & (temporary quitters) pada waktu $t$ & \\
\hline$Q_{p}(t)$ & $\begin{array}{l}\text { Populasi perokok yang berhenti secara permanen } \\
\text { (permanent quitters) pada waktu } t\end{array}$ & Orang \\
\hline$\Lambda$ & $\begin{array}{l}\text { Laju pertambahan populasi berpotensi merokok } \\
\text { baik melalui proses kelahiran maupun migrasi }\end{array}$ & Orang/tahun \\
\hline$\beta_{1}$ & $\begin{array}{l}\text { Laju perpindahan individu dari potential smokers } \\
(P) \text { ke individu yang berada pada snuffing class } \\
(S)\end{array}$ & $\begin{array}{l}1 / \text { (waktu } x \\
\text { orang) }\end{array}$ \\
\hline$\beta_{2}$ & $\begin{array}{l}\text { Laju perpindahan individu dari snuffing class }(S) \\
\text { ke irregular smokers }(X)\end{array}$ & $\begin{array}{l}1 / \text { (waktu } x \\
\text { orang) }\end{array}$ \\
\hline$\rho$ & $\begin{array}{l}\text { Laju pengurangan populasi pada snuffing class }(S) \\
\text { karena penggunaan tembakau }\end{array}$ & $1 /$ tahun \\
\hline$\mu$ & $\begin{array}{lllll}\begin{array}{l}\text { Laju kematian } \\
\text { kompartemen }\end{array} & \text { alami populasi di } & \text { semua } \\
\end{array}$ & $1 /$ tahun \\
\hline$\eta$ & $\begin{array}{l}\text { Laju kematian populasi irregular smokers }(X) \\
\text { karena penyakit }\end{array}$ & $1 /$ tahun \\
\hline$\omega$ & $\begin{array}{l}\text { Laju perpindahan populasi irregular smokers }(X) \\
\text { menjadi populasi regular smokers }(Y)\end{array}$ & $1 /$ tahun \\
\hline$\alpha$ & $\begin{array}{l}\text { Laju individu yang berhenti merokok sementara } \\
\text { kembali kambuh atau memiliki keinginan untuk } \\
\text { kembali merokok }\end{array}$ & $1 /$ tahun \\
\hline$\gamma$ & Laju individu berhenti merokok & $1 /$ tahun \\
\hline$\delta$ & Proporsi perokok yang berhenti sementara & - \\
\hline$(1-\delta)$ & Proporsi perokok yang berhenti permanen & - \\
\hline$\tau_{1}$ & Efektitiftas kampanye edukasi & - \\
\hline$\tau_{2}$ & Efektifitas pengobatan & - \\
\hline$u_{1}$ & $\begin{array}{l}\text { Proporsi kampanye edukasi yang dilakukan, } \\
0 \leq u_{1} \leq 1\end{array}$ & - \\
\hline$u_{2}$ & Proporsi pemberian obat anti nikotin , $0 \leq u_{2} \leq 1$ & - \\
\hline
\end{tabular}

\section{Masalah Kontrol Optimal}

Pada penelitian ini permasalahan kontrol optimal akan diselesaikan dengan tujuan untuk meminimumkan jumlah individu yang merokok dengan biaya penerapan kontrol $u_{1}$ dan $u_{2}$ yang minimum pula. Fungsi tujuan yang akan diminimumkan didefinisikan sebagai berikut:

$$
\min _{\left(u_{1}, u_{2}\right)} J=\min _{\left(u_{1}, u_{2}\right)} \int_{t_{0}}^{t_{f}}\left[A_{1} S(t)+A_{2} X(t)+A_{3} Y(t)+\frac{B_{1}}{2} u_{1}{ }^{2}(t)+\frac{B_{2}}{2} u_{2}{ }^{2}(t)\right] d t
$$

dimana kontrol optimal berada pada $0 \leq u_{1}, u_{2} \leq 1,0 \leq t \leq t_{f}$ dengan $t_{f}$ merupakan waktu akhir pengontrolan, koefisien $A_{1}$ merupakan nilai bobot tujuan untuk mengurangi jumlah individu dalam snuffing class, koefisien $A_{2}$ merupakan nilai bobot tujuan untuk mengurangi jumlah irregular smokers, koefisien $A_{3}$ merupakan nilai bobot tujuan untuk mengurangi jumlah regular smokers, koefisien $B_{1}$ merupakan nilai bobot tujuan dari fungsi kontrol $u_{1}$ yaitu upaya kampanye edukasi, dan koefisien $B_{2}$ merupakan nilai bobot tujuan dari fungsi kontrol $u_{2}$ yaitu upaya pemberian obat anti nikotin. Dengan kata lain, Persamaan (3.1) merepresentasikan pencarian fungsi kontrol $\left(u_{1}{ }^{*}, u_{2}{ }^{*}\right) \in U$ sedemikian sehingga $J\left(u_{1}{ }^{*}, u_{2}{ }^{*}\right) \leq J\left(u_{1}, u_{2}\right)$ untuk setiap $\left(u_{1}, u_{2}\right) \in U$.

\section{Pembentukan Persamaan State, Costate, dan Syarat Kestasioneran}

Pada persamaan (3.1) diberikan masalah optimasi, kemudian akan ditentukan kontrol optimal $u^{*}$ yang memenuhi $J\left(u^{*}\right)=\min \{J(u): u \in U\}$. Pencarian kontrol optimal $u^{*}$ dengan 


\section{Jurnal Matematika, Statistika E Komputasi}

\section{Andi Utari Samsir, Syamsuddin Toaha, Kasbawati}

menggunakan prinsip minimum Pontryagin yaitu menentukan fungsi Hamiltonian dari fungsi tujuan. Bentuk umum dari fungsi Hamiltonian adalah:

$$
H(t, x, u, \lambda)=f(t, x, u)+\lambda^{T}(t) g(t, x, u),
$$

dengan

$$
f(t, x, u)=A_{1} S(t)+A_{2} X(t)+A_{3} Y(t)+\frac{B_{1}}{2} u_{1}{ }^{2}(t)+\frac{B_{2}}{2} u_{2}{ }^{2}(t),
$$

dengan pengali Lagrange dari Persamaan (2.1)

$$
\lambda=\left(\begin{array}{llllll}
\lambda_{1} & \lambda_{2} & \lambda_{3} & \lambda_{4} & \lambda_{5} & \lambda_{6}
\end{array}\right)^{T},
$$

maka fungsi Hamilton dapat diuraikan seperti berikut:

$$
\begin{aligned}
H= & A_{1} S+A_{2} X+A_{3} Y+\frac{B_{1}}{2} u_{1}{ }^{2}+\frac{B_{2}}{2} u_{2}{ }^{2} \\
& +\lambda_{1}\left(\Lambda-\beta_{1} P S-\mu P\right) \\
& +\lambda_{2}\left(\beta_{1} P S-\beta_{2} S X-(\rho+\mu) S+\tau_{2} u_{2}(t) Y\right) \\
& +\lambda_{3}\left(\beta_{2} S X-(\eta+\omega+\mu) X-\tau_{1} u_{1}(t) X\right) \\
& +\lambda_{4}\left(\omega X-(\gamma+\mu) Y+\alpha\left(1-u_{1}(t)\right) Q_{t}-\tau_{2} u_{2}(t) Y\right) \\
& +\lambda_{5}\left(\gamma\left(1+u_{2}(t)\right) \delta Y-\left(\mu+\alpha\left(1-u_{1}(t)\right)\right) Q_{t}\right) \\
& +\lambda_{6}\left(\gamma\left(1+u_{2}(t)\right)(1-\delta) Y-\mu Q_{p}\right) .
\end{aligned}
$$

Dari Persamaan (4.1) diperoleh persamaan state berikut:

dengan

$$
\dot{x}=\frac{\partial H}{\partial \lambda}=\left(\frac{\partial H}{\partial \lambda_{1}} \frac{\partial H}{\partial \lambda_{2}} \frac{\partial H}{\partial \lambda_{3}} \frac{\partial H}{\partial \lambda_{4}} \quad \frac{\partial H}{\partial \lambda_{5}} \frac{\partial H}{\partial \lambda_{6}}\right)^{T}
$$

dengan

$$
\dot{x}=\frac{\partial H}{\partial \lambda}=\left(\frac{\partial H}{\partial \lambda_{1}} \frac{\partial H}{\partial \lambda_{2}} \frac{\partial H}{\partial \lambda_{3}} \frac{\partial H}{\partial \lambda_{4}} \frac{\partial H}{\partial \lambda_{5}} \frac{\partial H}{\partial \lambda_{6}}\right)^{T},
$$

$\frac{\partial H}{\partial \lambda_{1}}=\Lambda-\beta_{1} P S-\mu P$,

$\frac{\partial H}{\partial \lambda_{2}}=\beta_{1} P S-\beta_{2} S X-(\rho+\mu) S+\tau_{2} u_{2}(t) Y$,

$\frac{\partial H}{\partial \lambda_{3}}=\beta_{2} S X-(\eta+\omega+\mu) X-\tau_{1} u_{1}(t) X$,

$\frac{\partial H}{\partial \lambda_{4}}=\omega X-(\gamma+\mu) Y+\alpha\left(1-u_{1}(t)\right) Q_{t}-\tau_{2} u_{2}(t) Y$,

$\frac{\partial H}{\partial \lambda_{5}}=\gamma\left(1+u_{2}(t)\right) \delta Y-\left(\mu+\alpha\left(1-u_{1}(t)\right)\right) Q_{t}$,

$\frac{\partial H}{\partial \lambda_{6}}=\gamma\left(1+u_{2}(t)\right)(1-\delta) Y-\mu Q_{p}$.

Untuk persamaan costate diperoleh:

dengan

$$
\begin{aligned}
\dot{\lambda} & =-\frac{\partial H}{\partial x}=\left(\begin{array}{lllllll}
-\frac{\partial H}{\partial P} & -\frac{\partial H}{\partial S} & -\frac{\partial H}{\partial X} & -\frac{\partial H}{\partial Y} & -\frac{\partial H}{\partial Q_{t}} & -\frac{\partial H}{\partial Q_{p}}
\end{array}\right)^{T} \\
& =\left(\begin{array}{llllll}
\dot{\lambda}_{1} & \dot{\lambda}_{2} & \dot{\lambda}_{3} & \dot{\lambda}_{4} & \dot{\lambda}_{5} & \dot{\lambda}_{6}
\end{array}\right)^{T},
\end{aligned}
$$

$\dot{\lambda_{1}}=-\frac{\partial H}{\partial P}=-\lambda_{1}\left(-\beta_{1} S-\mu\right)-\lambda_{2} \beta_{1} S$.

$\dot{\lambda_{2}}=-\frac{\partial H}{\partial S}=-A_{1}+\lambda_{1} \beta_{1} P-\lambda_{2}\left(\beta_{1} P-\beta_{2} X-\mu-\rho\right)-\lambda_{3} \beta_{2} X$.

$\dot{\lambda_{3}}=-\frac{\partial H}{\partial X}=-A_{2}+\lambda_{2} \beta_{2} S-\lambda_{3}\left(\beta_{2} S-\tau_{1} u_{1}-\eta-\mu-\omega\right)-\lambda_{4} \omega$.

$\dot{\lambda}_{4}=-\frac{\partial H}{\partial Y}=-A_{3}-\lambda_{2} \tau_{2} u_{2}-\lambda_{4}\left(-\tau_{2} u_{2}-\gamma-\mu\right)-\lambda_{5} \gamma\left(1+u_{2}\right) \delta-\lambda_{6} \gamma\left(1+u_{2}\right)(1-\delta)$.

$\dot{\lambda}_{5}=-\frac{\partial H}{\partial Q_{t}}=-\lambda_{4} \alpha\left(1-u_{1}\right)-\lambda_{5}\left(-\mu-\alpha\left(1-u_{1}\right)\right)$.

$\dot{\lambda}_{6}=-\frac{\partial H}{\partial Q_{p}}=\lambda_{6} \mu$. 


\section{Jumal Matematika, Statistika \& Komputasi Andi Utari Samsir, Syamsuddin Toaha, Kasbawati}

Bentuk $u_{1}$ dan $u_{2}$ yang optimal diperoleh dengan menggunakan syarat stasioner diberikan oleh:

Dari syarat stasioner tersebut diperoleh:

$$
\frac{\partial H}{\partial u}=\left(\frac{\partial H}{\partial u_{1}} \frac{\partial H}{\partial u_{2}}\right)^{T}=0 .
$$

$$
\begin{gathered}
u_{1}=\frac{-\left(\lambda_{5}-\lambda_{4}\right) \alpha Q_{t}+\lambda_{3} \tau_{1} X}{B_{1}}, \\
u_{2}=\frac{-\left(\lambda_{2}-\lambda_{4}\right) \tau_{2} Y-\left(\lambda_{5} \delta+\lambda_{6}(1-\delta)\right) \gamma Y}{B_{2}} .
\end{gathered}
$$

Sehingga diperoleh kontrol optimal $u_{1}^{*}$ dan $u_{2}^{*}$ sebagai berikut:

$$
\begin{gathered}
u_{1}{ }^{*}=\min \left\{\max \left\{0, \frac{-\left(\lambda_{5}-\lambda_{4}\right) \alpha Q_{t}+\lambda_{3} \tau_{1} X}{B_{1}}\right\}, 1\right\}, \\
u_{2}{ }^{*}=\min \left\{\max \left\{0, \frac{-\left(\lambda_{2}-\lambda_{4}\right) \tau_{2} Y-\left(\lambda_{5} \delta+\lambda_{6}(1-\delta)\right) \gamma Y}{B_{2}}\right\}, 1\right\} .
\end{gathered}
$$

\section{Simulasi Numerik}

Pada bagian ini, dilakukan simulasi numerik untuk mendapatkan solusi optimal sistem. Metode numerik yang digunakan adalah metode forward-backward Sweep. Interval waktu $\left[t_{0}, t_{f}\right]$ yaitu $t_{0}=0$ dan waktu $t_{f}=30$ tahun. Begitu pula dengan fungsi kontrol $u_{i}=$ $\left(u_{i_{1}}, u_{i_{2}}, \cdots, u_{i_{n}}\right)$ dengan $u_{i_{j}} \approx u_{i}\left(b_{j}\right), i=1,2$ dan $j=1,2, \cdots, n$. Pada metode tersebut solusi $x(t)$ dan $\lambda(t)$ dicari dengan menggunakan metode forward-backward Runge-Kutta orde 4. Sedangan nilai $u_{i}$ diperbaharui disetiap iterasi menggunakan $u=\frac{\left(u_{a w a l}+u_{b a r u}\right)}{2}$, dengan $u_{\text {baru }}$ diperoleh dari syarat keoptimalan $\frac{\partial H}{\partial u}=0$ [12]. Diasumsikan nilai awal dari masing-masing populasi adalah $P(0)=3000$ individu, $S(0)=2000$ individu, $X(0)=1000$ individu, $Y(0)=2000$ individu, $Q_{t}(0)=1000$ individu dan $Q_{p}(0)=1000$, nilai bobot yang digunakan $A_{1}=20, A_{2}=20, A_{3}=60, B_{1}=50$, dan $B_{2}=50$ dengan parameter yang digunakan yaitu $\Lambda=1000, \beta_{1}=0.003, \beta_{2}=0.002, \rho=0.003, \mu=0.002, \eta=0.003, \omega=0.004, \alpha=1, \gamma=$ $0.05, \delta=0.5, \tau_{1}=0.5, \tau_{2}=0.5$.

Simulasi terhadap populasi potential smokers $(P)$ ditunjukkan pada Gambar 5.1. Pada gambar tersebut, kedua populasi baik dengan kontrol maupun tanpa kontrol mengalami penurunan sejak tahun pertama secara bersamaan dan kemudian kedua populasi mengalami peningkatan. Populasi potential smokers tanpa kontrol terus meningkat dengan cepat hingga akhir waktu pengamatan. Sedangkan untuk populasi dengan kontrol optimal, peningkatan terjadi hingga awal tahun ketiga dimana populasi potential smokers dengan kontrol optimal bertambah lebih sedikit dibandingkan dengan populasi tanpa kontrol. Populasi dengan kontrol optimal terus mengalami penurunan secara perlahan hingga tahun ke tujuh belas dan akhirnya stabil hingga akhir waktu pengamatan.

Gambar 5.2 menunjukkan grafik perbandingan individu dalam snuffing class $(S)$ dengan kontrol dan tanpa kontrol. Pada gambar tersebut terlihat bahwa di awal tahun pertama kedua populasi mengalami sedikit peningkatan dan kemudian turun dengan cepat secara bersamaan hingga akhir tahun pertama. Kemudian populasi tanpa kontrol tidak mengalami perubahan hingga tahun keenam namun di tahun ketujuh populasi meningkat hingga tahun kedelapan, populasi kembali stabil hingga enam tahun berikutnya dan kembali meningkat selama satu tahun dan akhirnya populasi stabil hingga akhir tahun pengamatan. Sedangkan untuk populasi snuffing class dengan kontrol, populasi perlahan meningkat dari tahun pertama hingga tahun ke empat kemudian turun di tahun kelima dan akhirnya stabil hingga akhir waktu pengamatan. Peningkatan pada populasi setelah dikontrol disebabkan adanya individu perokok aktif yang berkurang setelah diberikan kontrol dan kemudian masuk dalam snuffing class . 


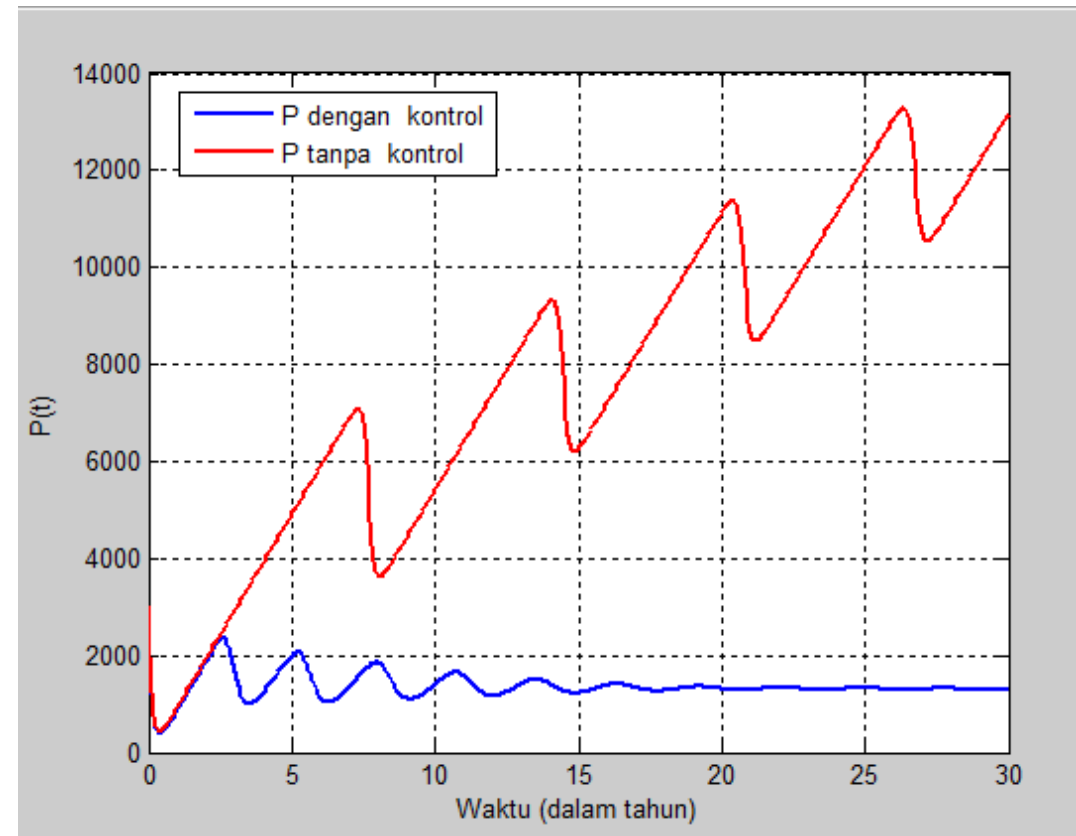

Gambar 5.1 Grafik Perubahan Potential Smokers dalam Populasi terhadap Waktu $(t=30$ tahun)

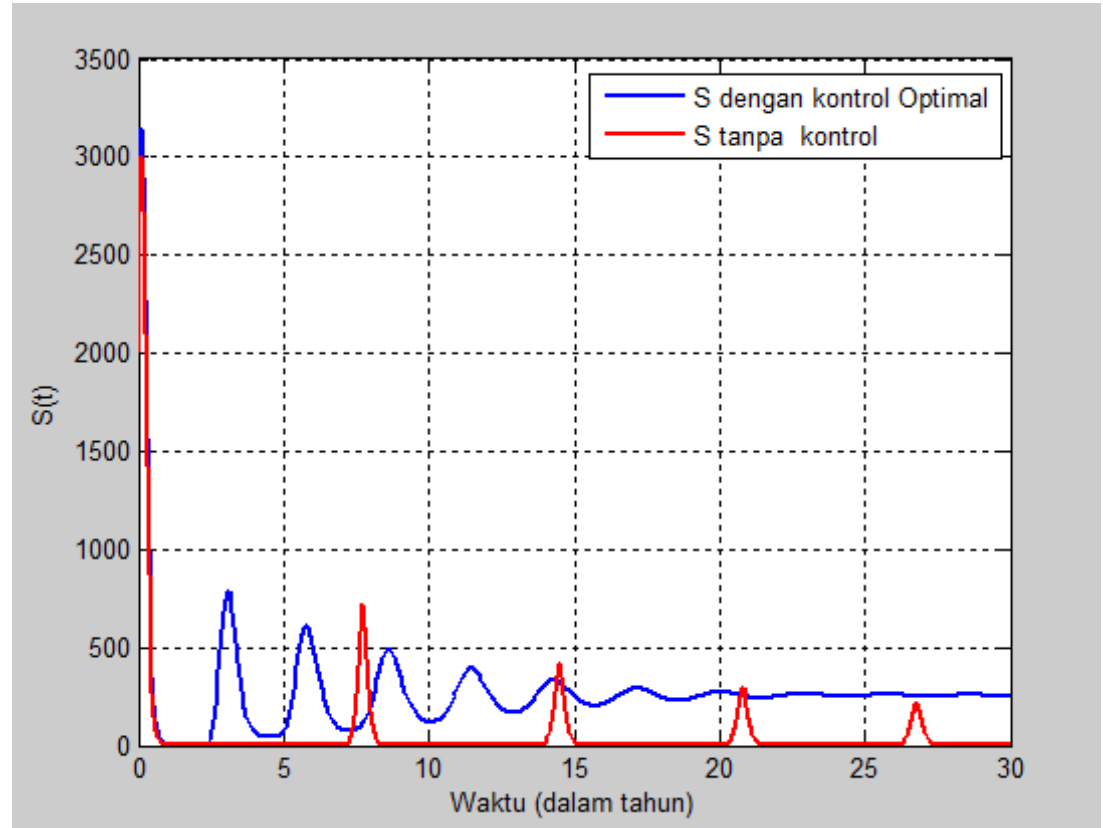

Gambar 5.2 Grafik Perubahan Snuffing Class dalam Populasi terhadap Waktu ( $t=30$ tahun) 


\section{Jumal Matematika, Statistika \& Komputasi Andi Utari Samsir, Syamsuddin Toaha, Kasbawati}

Simulasi populasi irregular smokers $(X)$ ditunjukkan pada Gambar 5.3. Pada gambar tersebut, kedua populasi baik dengan kontrol maupun tanpa kontrol mengalami peningkatan sejak tahun pertama dimana jumlah populasi dengan kontrol meningkat lebih sedikit dibandingkan dengan populasi tanpa kontrol. Selanjutnya populasi tanpa kontrol terus meningkat hingga akhir waktu pengamatan sedangkan populasi dengan kontrol mengalami penurunan hingga tahun keempat belas dan kemudian stabil hingga akhir waktu pengamatan. Hal ini menunjukkan bahwa jumlah individu irregular smokers $(X)$ dapat dikurangi dengan memberikan kontrol berupa kampanye edukasi.

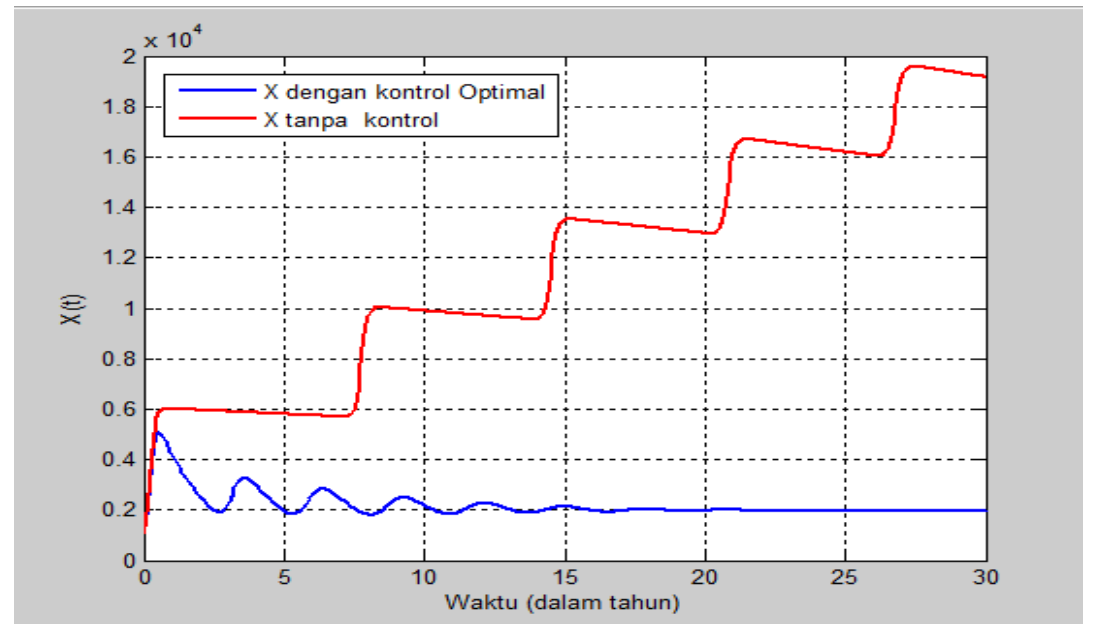

Gambar 5.3 Grafik Perubahan Irregular Smokers dalam Populasi terhadap Waktu ( $t=30$ tahun)

Gambar 5.4 menunjukkan grafik perbandingan populasi regular smokers $(Y)$ dengan kontrol dan tanpa kontrol. Pada gambar tersebut terlihat jelas perbedaan antar kedua populasi. Populasi tanpa kontrol terus mengalami peningkatan hingga akhir waktu pengamatan sedangkan populasi dengan kontrol terus menurun hingga tahun kedelapan belas dan kemudian stabil hingga akhir waktu pengamatan. Hal ini berarti bahwa pemberian kontrol berupa obat anti nikotin pada populasi perokok aktif atau regular smokers memberikan hasil yang baik.

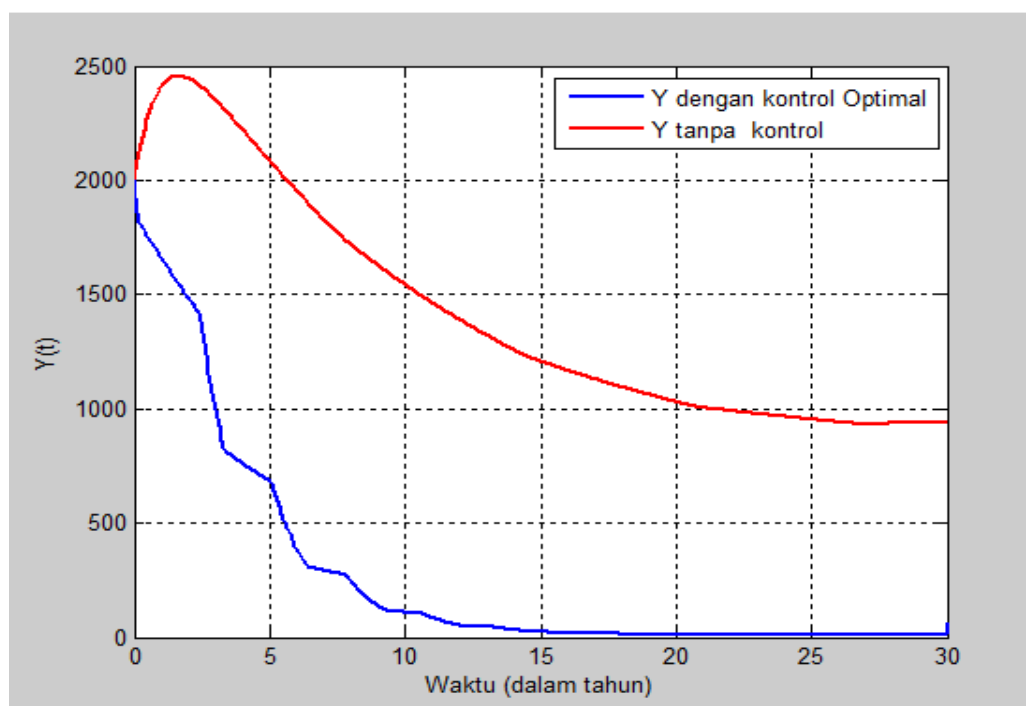

Gambar 5.4 Grafik Perubahan Regular Smokers dalam Populasi terhadap Waktu ( $t=30$ tahun) 


\section{Jumal Matematika, Statistika \& Komputasi}

\section{Andi Utari Samsir, Syamsuddin Toaha, Kasbawati}

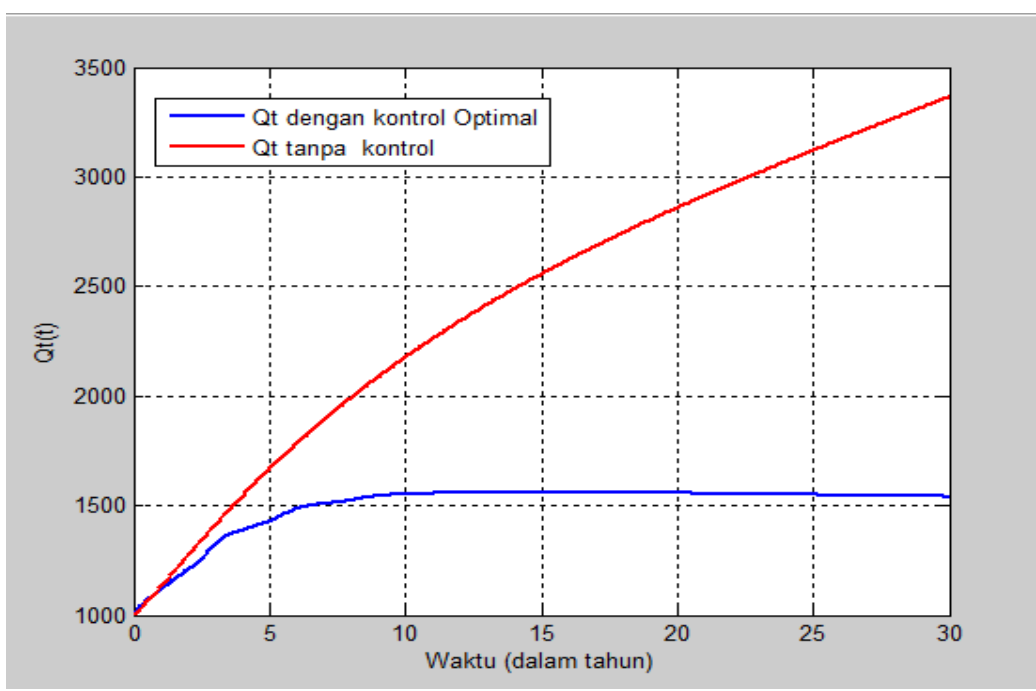

Gambar 5.5 Grafik Perubahan Temporary Quitters dalam Populasi terhadap Waktu $(t=30$ tahun)

Simulasi terhadap populasi perokok yang berhenti sementara atau temporary quitters $\left(Q_{t}\right)$ ditunjukkan pada Gambar 5.5. Pada gambar tersebut menunjukkan bahwa populasi yang telah dikontrol maupun tanpa kontrol mengalami peningkatan, namun peningkatan lebih sedikit terjadi pada populasi yang telah dikontrol. Hal ini disebabkan karena adanya perokok yang kembali menjadi perokok aktif.

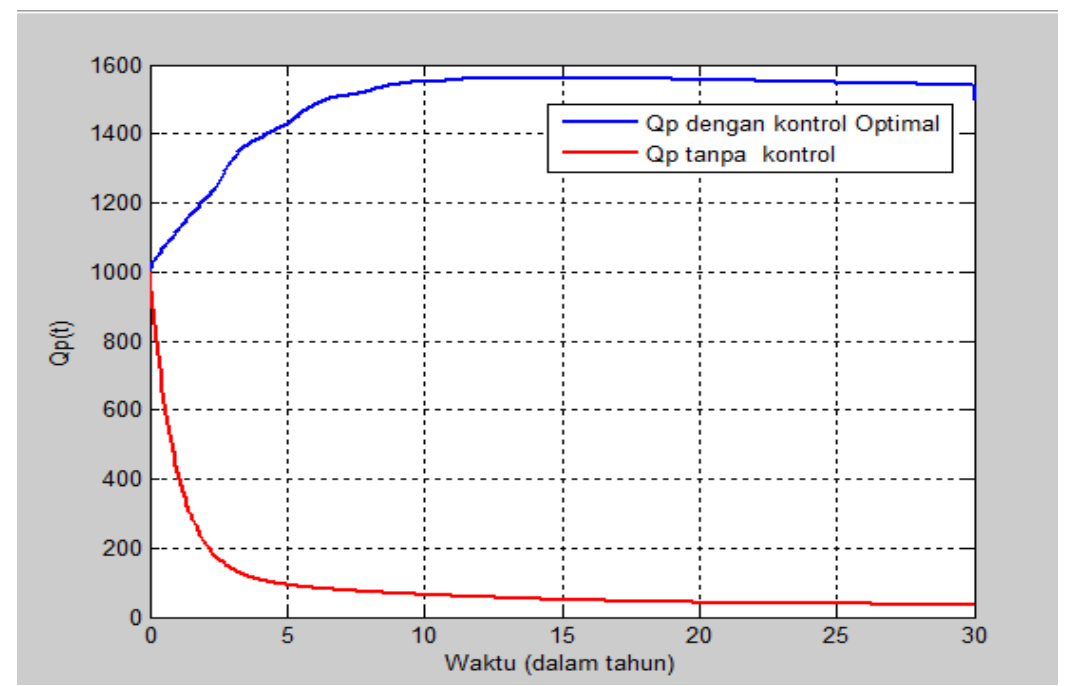

Gambar 5.6 Grafik Perubahan Permanent Quitters dalam Populasi terhadap Waktu $(t=30$ tahun)

Sedangkan Gambar 5.6 menunjukkan grafik perbandingan populasi perokok yang berhenti secara permanen atau permanent quitters $\left(Q_{p}\right)$. Pada gambar tersebut terlihat bahwa populasi yang telah dikontrol mengalami peningkatan. Hal ini berarti bahwa penerapan kontrol berupa pemberian obat anti nikotin dapat meningkatkan jumlah individu yang berhenti merokok secara permanen. 


\section{Jumal Matematika, Statistika \& Komputasi Andi Utari Samsir, Syamsuddin Toaha, Kasbawati}

Pada pemaparan sebelumnya, telah dijelaskan bahwa terdapat dua macam konrol dalam model perilaku merokok ini, yaitu kontrol $u_{1}(t)$ merupakan upaya kampanye edukasi dan kontrol $u_{2}(t)$ merupakan upaya pemberian obat anti nikotin. Adapun bentuk grafik yang optimal dari $u_{1}(t)$ dan $u_{2}(t)$ ditunjukkan pada Gambar 5.7.

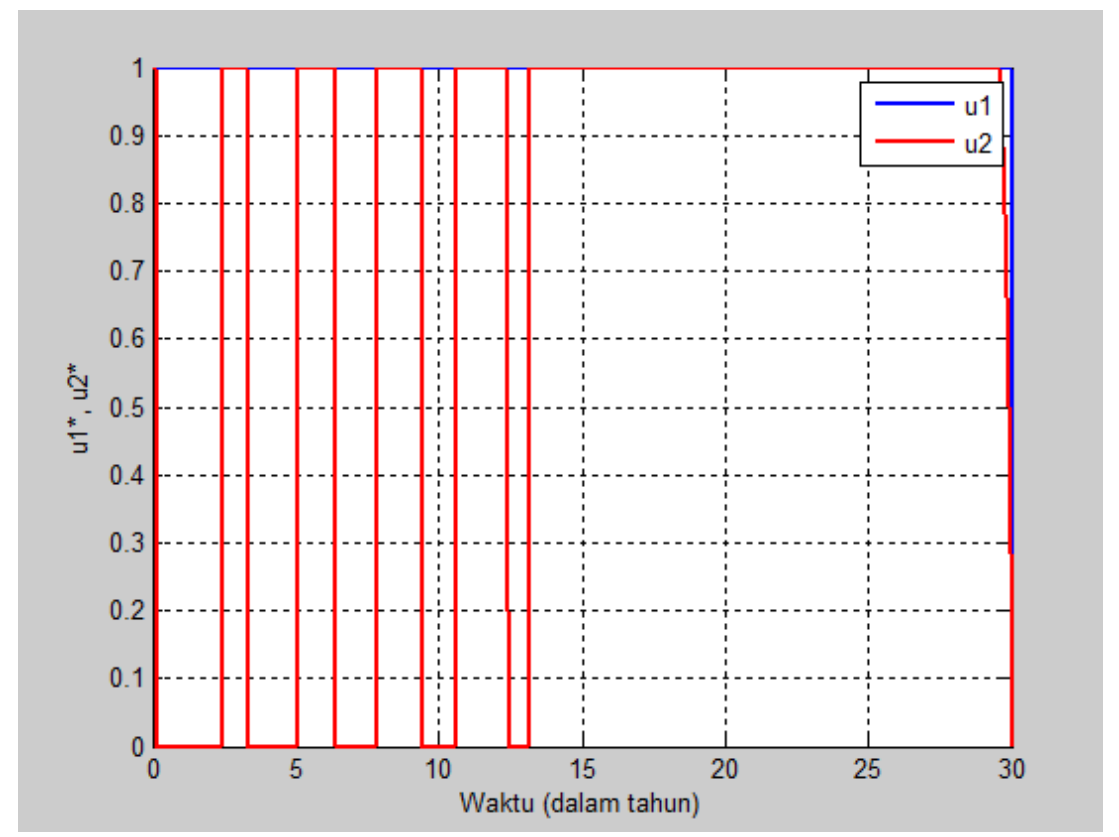

Gambar 5.7 Grafik Perbandingan Fungsi Kontrol Optimal $u_{1}^{*}(t)$ dan $u_{2}^{*}(t)$

Gambar 5.7 menunjukkan perbandingan dari kedua kontrol. Pada waktu awal, $u_{1}(t)$ dan $u_{2}(t)$ mencapai nilai optimal yang berarti bahwa kampanye edukasi dan pemberian obat anti nikotin dalam jumlah besar perlu dilakukan sejak awal. Pada gambar tersebut terlihat bahwa kontrol $u_{1}(t)$ tidak mengalami perubahan hingga akhir waktu pengamatan. Hal ini berarti bahwa untuk menekan jumlah populasi perokok secara maksimal, kampanye edukasi harus dilakukan secara terus menerus. Sedangkan pada kontrol $u_{2}(t)$, dari tahun pertama hingga tahun kesembilan belas kontrol $u_{2}(t)$ bernilai nol dan satu dan kemudian turun secara cepat mencapai nilai nol di akhir waktu pengamatan. Penurunan ini terjadi karena semakin berkurangnya populasi perokok aktif setelah dikontrol yang mengakibatkan proporsi kontrol berupa pemberian obat anti nikotin semakin berkurang karena tidak ada lagi individu yang akan dikontrol.

\section{Kesimpulan}

Model matematika perilaku merokok dikembangkan dengan enam kompartemen yaitu Potential Smokers $(P)$, Snuffing Class $(S)$, perokok ringan atau Irregular Smokers $(X)$, perokok berat atau Regular Smokers $(Y)$, Temporary Quitters $\left(Q_{t}\right)$, dan Permanent Quitters $\left(Q_{p}\right)$ dengan penerapan kontrol optimal berupa upaya kampanye edukasi dan pemberian obat anti nikotin. Diperoleh dua bentuk kontrol optimal yaitu:

$$
\begin{gathered}
u_{1}{ }^{*}=\min \left\{\max \left\{0, \frac{-\left(\lambda_{5}-\lambda_{4}\right) \alpha Q_{t}+\lambda_{3} \tau_{1} X}{B_{1}}\right\}, 1\right\}, \\
u_{2}{ }^{*}=\min \left\{\max \left\{0, \frac{-\left(\lambda_{2}-\lambda_{4}\right) \tau_{2} Y-\left(\lambda_{5} \delta+\lambda_{6}(1-\delta)\right) \gamma Y}{B_{2}}\right\}, 1\right\} .
\end{gathered}
$$

Berdasarkan hasil simulasi numerik, diperoleh bahwa dengan penerapan kontrol berupa kampanye edukasi dan pemberian obat anti nikotin dapat mengurangi populasi perokok dengan 


\section{Jumal Matematika, Statistika \& Komputasi Andi Utari Samsir, Syamsuddin Toaha, Kasbawati}

cepat dan meningkatkan perokok yang berhenti secara permanen. Penerapan kontrol optimal berupa upaya penerapan kampanye edukasi berada pada nilai maksimal dari awal hingga akhir tahun pengamatan dibandingkan dengan upaya pemberian obat anti nikotin yang mencapai nilai nol di akhir pengamatan. Hal ini berarti bahwa masyarakat perlu diberikan edukasi lebih lama untuk mengurangi perilaku merokok.

\section{Daftar Pustaka}

[1] Agustianingsih S., Reorita R. \& Renny., 2020. Kontrol Optimal pada Model SIR dengan Pengaruh Vaksinasi, Karantina, dan Faktor Imigrasi. Jurnal Matematika, Statistika \& Komputasi. Vol. 16, No. 3, 311-324.

[2] Alkhudhari Z., Al-Sheikh S. \& Al-Tuwairqi S., 2014. Global Dynamics of a Mathematical Model on Smoking. ISRN Applied Mathematics, Vol. 2014, 1-8.

[3] Alkhudhari Z., Al-Sheikh S. \& Al-Tuwairqi S., 2014. The Effect of Occasional Smokers on The Dynamics of a Smoking Model. International Mathematical Forum, Vol. 9, No. 25, 1207-1222.

[4] Alkhudhari Z., Al-Sheikh S. \& Al-Tuwairqi S., 2015. The Effect of Heavy Smokers on The Dynamics of a Smoking Model. International Journal of Differential Equations and Applications, Vol. 14, No. 4, 343-356.

[5] Alzahrani E. \& Zeb A., 2020. Stability Analysis and Prevention Strategies of Tobacco Smoking Model. Springer Open Journal, Vol. 2020, No. 3, 1-13.

[6] Anggriani N., Toaha S. \& Kasbawati., 2021. Kontrol Optimal Model Matematika terhadap Dinamika Penyebaran Penyalahgunaan Narkoba. Jurnal Matematika, Statistika \& Komputasi. Vol. 17, No. 3, 339-348.

[7] Cahyono E., 2013. Pemodelan Matematika, Edisi Pertama. Graham Ilmu., Yogyakarta.

[8] Din Q., Ozair M., Hussain T. \& Saeed U., 2016. Qualitative Behavior of Smoking Model. Advance in Difference Equations, Vol. 2016(2016), No. 96, 1-12.

[9] Garsow, C.C., Salivia, G.J. \& Herrera, A.A., 1997. Mathematical Models for The Dynamics of Tobacco Use, Recovery and Relapse. Technical Report Series BU-1505-M.

[10] Guerrero F., Santonja, F.J. \& Villanueva, R.J., 2011. Analysing The Spanish Smoke-Free Legislation of 2006: A New Method to Quantify Its Impact Using a Dynamic Model. International Journal of Drug Policy, Vol. 22, 247-251.

[11] Kemenkes RI., 2018. Hasil Utama RISKESDAS 2018. Badan Penelitian dan Pengembangan Kesehatan Kementerian Kesehatan RI., Jakarta.

[12] Lenhart S. \& Workman J., 2007. Optimal Control Applied to Biological Models. Chapman $\&$ Hall., New York.

[13] Matintu, S.A. 2017. Smoking as Epidemic: Modeling and Simulation Study. American Journal of Applied Mathematics, Vol. 5, No. 1, 31-38.

[14] Pang L., Zhao Z., Liu S. \& Zhang X., 2015. A Mathematical Model Approach for Tobacco Control in China. Applied Mathematics and Computation, Vol. 259, 497-509.

[15] Pang L., Liu S., Zhang X \& Tian T., 2019. The Cost-Effectiveness Analysis and Optimal Strategy of the Tobacco Control. Computational and Mathematical Methods in Medicine. Vol. 2019, 1-15.

[16] Salawati T \& Indrawati, N. D., 2016. Analisis Kebutuhan untuk Merancang Komik Anak "Asetaro" (Aku Akan Tetap Sehat Tanpa Rokok). Jurnal Kesehatan Masyarakat, Vol. 11, No. 2, 96-105.

[17] Sharomi O \& Gumel, A.B., 2008. Curtaling Smoking Dynamics: A Mathematical Modeling Approach. Applied Mathematics and Computation, Vol. 195, 475-499.

[18] Sikander W., Khan U., Ahmed N. \& Mohyud-Din, S.T., 2017. Optimal Solutions for a Bio Mathematical Model for The Evolution of Smoking Habit. Result in Physic, Vol. 7, 510517. 


\section{Jumal Matematika, Statistika \& Komputasi}

Andi Utari Samsir, Syamsuddin Toaha, Kasbawati

[19] Verma V., 2020. Optimal Control Analysis of a Mathematical Model on Smoking. Modelling Earth Systems and Environment. doi.org/10.1007/s40808-020-00847-1.

[20] WHO (World Health Organization). 2019. WHO Launches New Report On Global Tobacco Use Trends. Publishing, Switzerland. https://www.who.int/news/item/19-122019-who-launches-new-report-on-global-tobacco-use-trends. [26 November 2020].

[21] Zaman G., 2011. Qualitative Behavior of Giving Up Smoking Models. Bull.Malays.MathSci.Soc, Vol. 34, No. 2, 403-415.

[22] Zaman G., 2011. Optimal Campaign in The Smoking Dynamics. Computational and Mathematical Methods in Medicine, 1-9.

[23] Zeb A., Zaman G. \& Momani S., 2013. Square-root Dynamics of a Giving Up Smoking Model. Applied Mathematical Modelling, Vol. 37, 5326-5334. 